ISSN1027-5495. Functional Materials, 23, No.3 (2016), p. 437-442

doi:http://dx.doi.org/10.15407/fm23.03.437

(C) 2016 - STC “Institute for Single Crystals"

\title{
Determination of free phenolics and combined phenolics in foliage of Magnolia sieboldii K. Koch
}

\author{
Gao Hongbing, Wang Huan, Du Fengguo
}

\author{
The Provincial Key Laboratory on Forestry and Ecological Environment of \\ Beihua University, Jilin City, 132013, P.R. China
}

Received Marh 28, 2016

\begin{abstract}
In order to further understand the type and content of phenolics of Magnolia sieboldii K. Koch, the method of high performance liquid chromatography (HPLC) was used for measuring qualitatively and quantitatively free phenolics, combined phenolics and ester phenolics in foliage. Chromatographic conditions: C18 column, Mobile phase A pump 0.5\% formic acid aqueous solution, B pump is $0.5 \%$ Formic acid methanol solution, The total flow rate of $0.8 \mathrm{ml} / \mathrm{min}$, the column temperature $30^{\circ} \mathrm{C}$,SPD detector. The experimental results showed that the foliage contained coumaric acid and chlorogenic acid of two kinds of free phenolics, caffeic acid, coumaric acid and catechin coumarin in combined state, coumarin and coumaric acid in ester form, content range was $0.012 \sim 5.31 \mathrm{mg} . \mathrm{L}^{-1}$. Various forms of coumaric acid widely existed in leaves.

Keywords: HPLC; Free phenolics; Combined phenolics; Ester phenolics; Magnolia sieboldii K. Koch
\end{abstract}

Методом высокоэффективной жидкостной хроматографии (ВЭЖХ ) исследовались качественно и количественно свободные фенолы, фенольные соединения и комбинированные сложные эдиры фенолы в листве магнолии Sieboldii K. Коха. Результаты показали , что листва содержала кумаровую кислоту и хлорогеновую двух видов свободных фенольных соединений, кофейную кислоту, кумаровую кислоту и катехин кумарина в связанном состоянии , кумарин и кумаровую кислоту в виде сложного эфира. Диапазон содержания был 0,012 5,31 mg.L- 1 . Различные формы кумаровой кислоты присутствовали в листьях .

Визначення вільних і комбінованих фенольних сполук в листі магнолії Sieboldii K. Коха. Гао Хонгбінгб Ванг Хуан, Ду Фенгіо

Методом високоефективної рідинної хроматографії (ВЕРХ) досліджувалися якісно і кількісно вільні феноли, фенольні сполуки і комбіновані складні ефріри феноли в листі магнолії Sieboldii К. Коха. Результати показали, що листя містила кумаровую кислоту і хлорогеновую двох видів вільних фенольних сполук, кавову кислоту, кумаровую кислоту і катехін кумарину в зв'язаному стані, кумарин і кумаровую кислоту у вигляді складного ефіру. Діапазон змісту був 0,012 5,31 mg.L- 1. Різні форми кумаровой кислоти присутні в листі.

\section{Introduction}

Magnolia sieboldii $\mathrm{K}$. Koch is a small deciduous arbor of Magnoliaceae. It is classified as one of the national rare and endangered plants in china. As a famous woody ornamental flower with not only beautiful foliage, flowers and fruits, but also fragrance, magnolia has aromatic oil in its flowers, fruits, leaves and roots, which can be used for extracting senior spices with high medicinal value. It is thus clear that magnolia has become a rare wild woody plant resource with high value for exploitation and utilization.

As key secondary products inside a plant, phenolic substances are widely distributed in various organs of a plant such as foliage, stem, skin, flowers and fruits, which have much in- 
fluence on the foliage colors, fruit flavor and quality of a plant. In recent years, it has been found that phenolic substances have multiple effects such as scavenging free radical, resisting membrane lipid oxidation, preventing cardiovascular disease, anti-aging and anti-cancer. Therefore, they have brought people's attention increasingly [1-3]. Meanwhile, phenolic substances have such effects inside a plant as disease resistance, injury resistance and radiation resistance [4].For example, free phenolics such as caffeic acid, catechol, tannic acid, rutin and cumaric acid can participate in disease resistant response [5].Besides, the plant disease resistance and the contents of phenolic compounds in tissues have much correlation [6]. The phenolic compounds can affect the cell membrane permeability and ATP formation, which can be further catalyzed and oxidized by polyphenolics oxidase and peroxidase into quinonoids, which act as bactericides to play a vital role in the plant disease resistance. There have been numerous reports on the phenolic substance determination in woody plants, including gas chromatographic method [7] and liquid chromatographic method [8-10]. Due to the complicated sample pretreatment of the gas chromatography, the liquid chromatography is much more applied. HPLC determination of free phenolics and combined phenolics in foliage shown in this paper has never been reported in the state.

\section{Materials and methods}

\subsection{Material collection}

In August, 2014, the test materials was collected from the fully expanded, mature and healthy leaves of the adult magnolia plants growing in Jiangnan Township of Fengman District of Jilin City. The test sample was frozen in liquid nitrogen and saved for use in a $-80^{\circ} \mathrm{C}$ refrigerator.

\subsection{Instruments and chromatographic conditions}

Instruments: High performance liquid chromatograph (Shimadzu Corporation), system configuration: SPD-M20A; diode array detector, automatic sampler and LC-20AT pump. Chromatographic column: C18 reversed phase column $(4.6 \mathrm{~mm} \times 250 \mathrm{~mm}$, 5um).Reagents: Chromatographic pure methanol, formic acid and ultrapure water. Standard materials: gallic acid, caffeic acid, ferulic acid, cumaric acid, chlorogenic acid, quercetin, rutin, catechin, epicatechin and coumarin. All the above standard materials ware purchased from National Institute for the Control of Pharmaceutical and Biological Products.

\subsection{Quantitative determination method}

Firstly carried out the detection of ten types of standard phenolics as per gradient elution condition mentioned in 1.3. Then conducted the sample determination. As to qualitative determination the phenolic substances in the sample were determined by comparing the retention time of the standard sample with UV graph. Determined the content of free phenolics quantitatively in the sample by means of external standard calibration curve. The peak area was measured under the maximum absorption wavelength. See Table 1 for the maximum absorption wavelength.

\section{Result and analysis}

\subsection{Extraction of phenolic substances}

Took $1 \mathrm{~g}$ of the test sample for cryogrinding. Added $30 \mathrm{ml}$ of $\mathrm{n}$-hexane. Shook it on the shaking table for $15 \mathrm{~min}$. to remove ester twice. Added $30 \mathrm{~mL}$ of methanol-acetone-water (volume ratio as 7:7:6) extractant for 20 minutes ultrasonic operation at room temperature. Conducted the extraction for 3 times. Then carried out the extraction filtration. Combined the filtrate for 3 times. The filtrate was used for the extraction of free phenolics and ester phnolics. And the filtration residue was used for the extraction of combined phenolics.

Carried out the vacuum concentration of the filtrate combined as above to the aqueous phase at $40^{\circ} \mathrm{C}$. Adjusted $\mathrm{pH}$ value of the solution to 2 with $4 \mathrm{~mol} / \mathrm{L}$ HCI. Conducted the centrifugation. Took the supernatant and remove the ester twice with $100 \mathrm{~mL}$-hexane. Conducted the extraction for 5 times with the mixed liquid of the isometric $100 \mathrm{~mL}$ ethyl acetate - anhydrous ether. Combined the extract and conduct the vacuum concentration to dry it at $30^{\circ} \mathrm{C}$. Metered volume to $5 \mathrm{~mL}$ with methanol solution to get the free phenolics. Passed it over $0.45 \mathrm{um}$ microfiltration membrane for HPLC determination. Combined the aqueous phase solution obtained by the extraction of ethyl acetate - anhydrous ether with the centrifugated sediment. Added $160 \mathrm{~mL}$ of $4 \mathrm{~mol} / \mathrm{L} \mathrm{NaOH}$ solution. Hydrolyzed it for $4 \mathrm{~h}$ away from light at room temperature. The rest procedures were the same as those of extracting free phenolics. Finally ester phnolics were obtained. Passed it over $0.45 \mathrm{um}$ microfiltration membrane for HPLC determination. Added $40 \mathrm{~mL}$ of $4 \mathrm{~mol} / \mathrm{L} \mathrm{NaOH}$ solution to the filtration residue obtained after the extraction and filtration of methanol-acetone-water mixture. Hydrolyzed it for $4 \mathrm{~h}$ away from light at room temperature. The rest procedures were the same as those of extracting free phenolics. Got the combined phenolics. The methods [11] 
Table. 1 Retention time of the standard material of the ten types of phenolics and the maximum absorption wavelength

\begin{tabular}{|c|c|c|}
\hline $\begin{array}{c}\text { Phenolic } \\
\text { compound }\end{array}$ & $\begin{array}{c}\text { Retention } \\
\text { time, min }\end{array}$ & $\begin{array}{c}\text { Maximum } \\
\text { absorption } \\
\text { wavelength, nm }\end{array}$ \\
\hline Gallic acid & 9.79 & 270 \\
\hline Catechin & 24.89 & 278 \\
\hline $\begin{array}{c}\text { Chlorogenic } \\
\text { acid }\end{array}$ & 31.21 & 327 \\
\hline Caffeic acid & 32.39 & 323 \\
\hline Epicatechin & 36.66 & 278 \\
\hline Coumaric acid & 45.23 & 309 \\
\hline Ferulic acid & 50.54 & 322 \\
\hline coumarin & 54.13 & 325 \\
\hline Rutin & 68.11 & 255 \\
\hline Quercetin & 73.04 & 374 \\
\hline
\end{tabular}

was referred to and slightly changed for the extraction of free phenolics, ester phnolics and combined phenolics. Passed it over 0.45 um microfiltration membrane filter for HPLC determination.

\subsection{The selection of chromatographic condition}

Methanol-water or acetonitrile-water shall be used generally as the mobile phase for the gradient elution in HPLC determination of phenolic substances. For the purpose of preventing carboxyl ionization of phenolics compounds from influencing the separation efficiency, acid is often needed for the addition in the mobile phase to make the mobile phase in acid conditions so as to inhibit phenolics carboxyl ionization, increase separation factor and improve the peak shape and resolution of each chromatographic peak [12]. $0.5 \%$ formic acid aqueous solution is contained in pump A. Pump B contained $0.5 \%$ formic acid methanol solution. The overall flow velocity was $0.8 \mathrm{~mL} / \mathrm{min}$. Car-

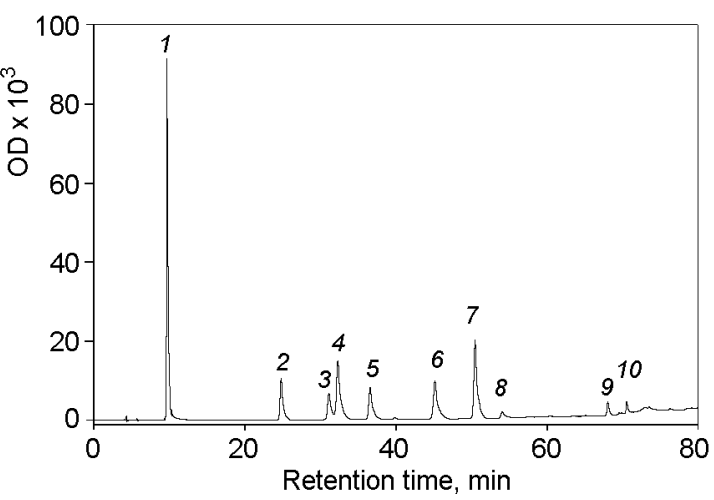

Fig. 1. Chromatogram of ten kinds of free phenolics

mixed standard. 1 - Gallic acid , 2 - catechins, 3 -Chlorogenic acid, 4 - Caffeic acid, 5 - Epicatechin, 6 - Coumaric acid, 7 - Ferulic acid, 8 - coumarin, 9 -Rutin, 10 -Querceti

ried out the gradient elution with the initial concentration as $10 \%$. The column temperature was $30^{\circ} \mathrm{C}$. The elution gradient of pump B was as follows. With $10 \%$ initial concentration, it increased to $18 \%$ in $15 \mathrm{~min}$. It increases to $25 \%$ in $35 \mathrm{~min}$. And it increases to $35 \%$ in $45 \mathrm{~min}$. Then the concentration is balanced again for 15 min. In $60 \mathrm{~min}$, it increased to $50 \%$, to $65 \%$ in $65 \mathrm{~min}$, and to $95 \%$ in $75 \mathrm{~min}$. Afterwards the flow velocity fell back to its initial concentration. And the separation column was balanced under such concentration for $10 \mathrm{~min}$. before the sample injection.

\subsection{The qualitative determination and} chromatographic separation effect

The qualitative determination of phenolic substances in the sample is conducted by means of the retention time of the standard material and the ultraviolet spectrum of the standard material. See Table 1 for the retention time for ten types of the standard material of phenolic substances.

As shown in Table 1, Gallic acid was the

Table 2. Linear regression equation, correlation coefficie-nt, linear range and detection limit

\begin{tabular}{|c|c|c|c|c|}
\hline Phebolic compound & $\begin{array}{c}\text { Linear regression } \\
\text { equation }\end{array}$ & $\begin{array}{c}\text { Correlation } \\
\text { coefficient }\end{array}$ & $\begin{array}{c}\text { Linearity range, } \\
\text { mg.L } \text {-1 }^{-1}\end{array}$ & $\begin{array}{c}\text { Detection limit, } \\
\text { mg.L }\end{array}$ \\
\hline Gallic acid & $y=50.156 x+18.51$ & 0.9998 & $0.05-99.12$ & 26.23 \\
\hline Catechin & $y=5.9865 x-17.26$ & 0.9985 & $0.06-98.46$ & 31.89 \\
\hline Chlorogenic acid & $y=31.804 x-23.11$ & 0.9995 & $0.03-350.26$ & 12.22 \\
\hline Caffeic acid & $y=22.734 x-56.95$ & 0.9993 & $0.05-99.65$ & 23.54 \\
\hline Epicatechin & $y=4.5681 x-27.92$ & 0.9948 & $0.06-97.48$ & 38.26 \\
\hline Coumaric acid & $y=21.631 x-64.36$ & 0.9993 & $0.03-99.32$ & 19.32 \\
\hline Ferulic acid & $y=36.381 x+5.46$ & 0.9992 & $0.036-12.57$ & 24.59 \\
\hline Coumarin & $y=3.0145 x-9.21$ & 0.9989 & $0.03-370.32$ & 15.14 \\
\hline Rutin & $y=39.601 x-1.001$ & 0.9996 & $0.02-98.21$ & 12.85 \\
\hline Quercetin & $y=26.147 x-15.69$ & 0.9997 & $0.90-99.78$ & 51.62 \\
\hline
\end{tabular}


Gao Hongbing et al. / High performance liquid chromatographic determination ...

Table 3. Recovery rate of the standard materials of phenolics

\begin{tabular}{|c|c|c|c|c|}
\hline \multirow{2}{*}{ Phenolic compound } & Added, $\mathrm{mg} \cdot \mathrm{L}^{-1}$ & Found, $\mathrm{mg} \cdot \mathrm{L}^{-1}$ & Recovery, $\%$ & RSD, \% \\
\hline Gallic acid & 1.52 & 1.36 & 89.47 & 1.21 \\
\hline Catechol & 1.63 & 1.47 & 90.18 & 2.49 \\
\hline Chlorogrnic acid & 1.56 & 1.13 & 72.43 & 1.87 \\
\hline Caffeic acid & 1.64 & 1.30 & 79.27 & 1.65 \\
\hline Epicatechin & 1.47 & 1.29 & 87.76 & 1.85 \\
\hline Coumaric acid & 1.52 & 1.45 & 95.39 & 1.02 \\
\hline Ferulic acid & 1.48 & 1.27 & 85.81 & 0.98 \\
\hline Coumarin & 1.41 & 1.19 & 84.39 & 1.16 \\
\hline Rutin & 1.46 & 1.21 & 82.87 & 1.31 \\
\hline Quercetin & 1.60 & 1.18 & 79.29 & 1.18 \\
\hline
\end{tabular}

first peak, its retention time was 9.79 minutes. Then it followed catechin, chlorogenic acid, caffeic acid, epicatechin, coumarin, ferulic acid, rutin and quercetin in turn. The retention time for the last peak of quercetin was $73.04 \mathrm{~min}$. The baseline began drifting upward since $75 \mathrm{~min}$ due to the use of gradient elution.

The chromatogram of ten kinds of standard phenolics as shown in Fig. 1. From the perspective of separation effect, 8 types of phenolics showed super separating effects. Only caffeic acid and chlorogenic acid showed a retention time difference of $1.28 \mathrm{~min}$. Although retention time of the two peaks were so close, but did not affect the quantitative accuracy.

\subsection{Linear relation and detection limit}

As shown in Table $\mathbf{2}$, the correlation coefficients of the ten types of phenolics all reached 0.99 and above, which meant good a linear relation within a certain limits. Chlorogenic acid and rutin had the wider linear ranges, which were $0.03-350 \mathrm{mg}^{-\mathrm{L}^{-1}}$ and $0.03-$ $370 \mathrm{mg} . \mathrm{L}^{-1}$ respectively. And the rest 8 types of phenolics had narrower linear ranges, which all fell in the range of $0.02-100 \mathrm{mg} . \mathrm{L}^{-1}$.The minimum detection limit was chlorogenic acid, which was $12.22 \mathrm{ug} . \mathrm{L}^{-1}$. The maximum detection limit was epicatechin, which was 38.26ug. $\mathrm{L}^{-1}$. Linear regression method was used in quantitative analysis results of HPLC determination for phenolics substances. Take maximimum absorption area as the independent variables, the content of phenolic substances as the dependent variable to set up linear regression equation.

\subsection{Recovery rate}

Added the standard phenolics to the blank solution before the extraction as per the phenolics extraction method in 2.1. Set up 3 repetitions and averaged it in the test. See from

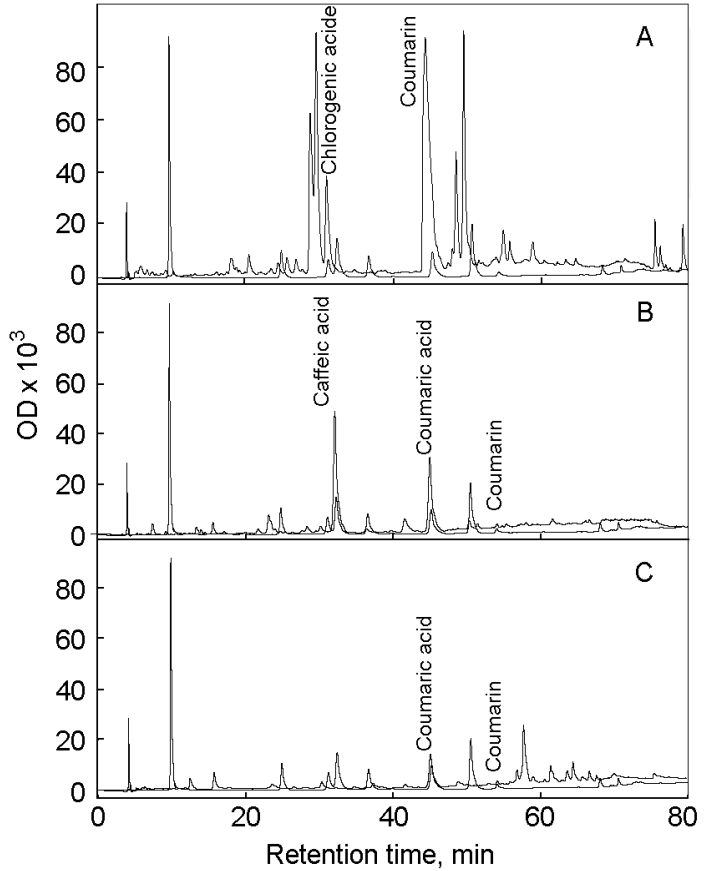

Fig. 2. The comparative chromatogram of free phenolics(A),combined phenolics(B) and ester phenolics(C) in leaveswith standard phenolics

table 3, coumaric acid recovery up to $95.39 \%$, followed by catechin, epicatechin, ferulic acid, coumarin, rutin and quercetin, caffeic acid and gallic acid. Chlorogenic acid was the lowest, to $72.43 \%$.Relative standard deviation was 0.98 $\sim 2.49 \%$ range and showed that the extracting method was accurate and reliable.

\subsection{Sample determination}

See Fig. 2 for the comparison of the detection chromatographs of free phenolics, combined phenolics and ester phenolics with the chromatographs of the ten types of standard materials. 
Table 4 . The determination results of phenolic compou-nds in leaves

\begin{tabular}{|c|c|c|c|}
\hline \multirow{2}{*}{$\begin{array}{l}\text { Phenolics } \\
\text { compound }\end{array}$} & \multicolumn{3}{|c|}{ Determination results $/ \mathrm{mg} \cdot \mathrm{g}^{-1}$} \\
\hline & $\begin{array}{c}\text { Free } \\
\text { phenolics }\end{array}$ & $\begin{array}{c}\text { Ester } \\
\text { phenolics }\end{array}$ & $\begin{array}{l}\text { Combined } \\
\text { phenolics }\end{array}$ \\
\hline Gallic acid & 0 & 0 & 0 \\
\hline Catechol & 0 & 0 & 0 \\
\hline $\begin{array}{l}\text { Chlorogrnic } \\
\text { acid }\end{array}$ & 0.75 & 0 & 0 \\
\hline Caffeic acid & 0 & 0 & 1.48 \\
\hline Epicatechin & 0 & 0 & 0 \\
\hline $\begin{array}{l}\text { Coumaric } \\
\text { acid }\end{array}$ & 5.31 & 0.57 & 1.11 \\
\hline Ferulic acid & 0 & 0 & 0 \\
\hline Rutin & 0 & 0 & 0 \\
\hline Quercetin & 0 & 0 & 0 \\
\hline Coumarin & 0 & 0.012 & 0.014 \\
\hline
\end{tabular}

The qualitative determination was conducted by comparing the retention time of the standard sample with UV chromatograph. The leaf contained two free phenolics such as chlorogenic acid and cumaric acid (Fig. 2A). The content of the latter was far more than that of the former. From Fig. 2B we arrived at the conclusion that the leaf contained three phenolics in combined state such as caffeic acid, cumaric acid and coumarin. The contents of the combined caffeic acid and cumaric acid were the higher than those of other phenolics. See Fig. 2C for the test result of the ester phenolics. The leaf contained ester phenolics in two forms which were cumaric acid and coumarin. See Table 4 for various phenolics contents in the sample.

As shown in Table 4 , there were two free phenolics, two este phenolics and three combined phenolics. The free phenolics were cumaric acid and chlorogenic acid. The content of cumaric acid was $5.31 \mathrm{mg} \cdot \mathrm{g}^{-1}$, which was much higher than the content of chlorogenic acid. The content of the combined caffeic acid was the highest, which was $1.48 \mathrm{mg} \cdot \mathrm{g}^{-1}$. The second was the combined cumaric acid, which was $1.11 \mathrm{mg} \cdot \mathrm{g}^{-1}$. The content of the combined coumarin was the lowest, which was $0.014 \mathrm{mg} \cdot \mathrm{g}^{-1}$. Two ester phenolics of coumarin and cumaric acid were mensured. The content of the latter was $0.57 \mathrm{mg} \cdot \mathrm{g}^{-1}$, which was more than 50 times that of esterified coumarin

\section{Result and discussion}

$80 \%$ methanol-water solution is usually used for the extraction of phenolic substances. It is mainly because that methanol has good solubility against most free phenolics and is able to inhibit the enzyme activity to prevent the oxidation of free phenolics in the extraction process. Methanol-acetone-water (volume ratio as 7:7:6) is used in this test for the extraction. It focuses on the extraction of the free phenolics. Meanwhile, it gives consideration to the extraction of the combined phenolics and ester phnol. Caffeic acid, chlorogenic acid, catechin and epicatechin in the free phenolics are unstable and easy to be oxidized and decomposed. As a result, the extraction should be conducted at low temperature and away from light as much as possible. The rotary thin film concentration should be heated at below $40^{\circ} \mathrm{C}$ so as to minimize the oxidation probability. As per the recovery rate of the free phenolics, the recovery rate of cumaric acid was the highest, which was as high as $95.39 \%$. The recovery rate of chlorogenic acid was the lowest, showing $72.43 \%$. The relative standard deviation was $0.98-2.49 \%$, which indicated that this extraction method was precise and reliable.

HPLC determination of phenolic substances has been much reported. Nian Hongli [8] measures 12 types of phenokic substance content in fructus corni. Sun Hongzhen [9] measures the phenolic substances in apple barks by means of HPLC. Shen Danhong [10] uses HPLC-MS to measure qualitatively and quantitatively 25 kinds of phenolics in tobacco. Methanol and water are used as the mobile phase in all the above mentioned studies. Besides, $1 \%$ acetic acid is added for the gradient elution so as to prevent hydrogen in hydroxyl and carboxyl groups of the phenolics from ionizing. The phenolic substances are kept in the state without charge so that superb peak shapes and separation effects can be obtained [12]. We improved the above studies in this test by adding $0.5 \%$ formic acid. Compare with acetic acid, formic acid has small molecules and good permeability, which can effectively reduce the column pressure. Good effects were achieved in terms of separation and peak shapes of the ten phenolics in this test.

There are some reports on the phenolics determination of woody plants. The materials in the determination mainly include the fruits of economic values. As an endangered tree species, magnolia has both ornamental value and some medicinal value. The free caffeic acid, cumaric acid and chlorogenic acid in plants have antioxidant property, bacteriostasis and antivirus effects [13]. They all belong to phenolics compounds, which are very unstable and easily degraded as a result of the influences such as external temperature, acidity and illumination [14]. The test result showed that various phenolics were contained in the leaf of magnolia. We detected two kinds of free phenolics such as cumaric acid and chlorogenic acid in the ten 
types of phenolics. The content of cumaric acid was much higher than that of chlorogenic acid. There were three kinds of combined phenolics, which were combined caffeic acid, combined cumaric acid and combined coumarin. The content of the combined caffeic acid was as high as $1.48 \mathrm{mg} . \mathrm{g}^{-1}$. The contents of combined cumaric acid, and combined coumarin were lower. Two types of ester phenolics were detected, which were coumarin ester phenolics and cumaric ester acid. The content of the latter was much higher than that of the former. The content of cumaric acid in leaves of magnolia was very high in free phenolics, combined phenolics and ester phnolics. It was interesting to observe in the test result that the combined caffeic acid content was quite high in the leaf, but no free caffeic acid had ever been detected. There was free chlorogenic acid in the leaf, but no combined chlorogenic acid were found. The combined phenolic substances inside the woody plants mainly and extensively reside in the plants cell walls by means of the combination of ether bond and acetal bond with cellulose.

\section{Conclusion}

In this study, the phenolics in magnolia leaves were determined by use of C18 reversed phase column for the gradient elution with $0.5 \%$ formic acid-water and formic acid-methanol solution as the mobile phase. The result showed that the magnolia leaf contained two free phenolics, three combined phenolics and two ester phnolics. Of the phenolics, cumaric acid was widely found in the three forms of phenolics. The content of it was the richest in free phenolics and ester phnolics. And in the combined phenolics the content of the combined caffeic acid was the highest, followed by the content of cumaric acid.

\section{Acknowledgements}

This work was financially supported by the fund of Jilin province department of science technology ( 20140101016 )and the fund of Jilin province department of education(172).

\section{References}

1. Ortiz D, Shea T B, J. Alzheimer's Disease, 6,27, 2004.

2. Qi Xiang-yang, Chen Wei-jun, Peng Guang-ua. Acta Nutr. Sinica, 25,397, 2003.

3. Xiangyang Qi, Weijun Chen, Guanghua Peng, Acta Nutr. Sinica, 2003, 25, 4 :397-400.

4. Liping Wang, Shengmao Zhou, Lidan Dai, Acta Agricult. Zhejiangensis, 22 (5), 696, 2010.

5. Xuejiao Feng, Xueli Cao, Yan Li, J. Beijing Techn. Bus. Univ. (Nat. Scie.e Ed. ), 26, 13, 2004.

6. N.W. Albert, D.H. Lewis, H. Zhang, J. Exp. Bot., 60(7), 2191, 2009.

7. Yanfang Zhang, Yunhong Yang, Guosui Su, Chem.Analys. Met., 19, 42, 2010.

8. Hongli Nian, He Li, Dongdong Cao, J. Beijing Forestry University, 33, 139, 2011.

9. Hongzhen Sun, Haitao Lu, Suhua Bai, Int. J. Fruit Scie. 29, 929, 2012.

10. Danhong Shen, Xin Lu, Yuwei Chang, Chinese J. Chromatography, 32 (1), 40, 2014.

11. Hongli Nian, Weibo Zhang, Ziping Xue,, J. Scie. Techn. Food Ind., 30 (11), 65, 2009.

12. Zhonggao Jiao, Jiechao Liu, Hongping Zhou, J. Beijing Techn. Bus. Univ. (Nat. Scie.e Ed. ) 34, 133, 2008

13. Xiaofang Zhao.Studies on the Relationship between Defense substances and Pathogen of Ring Rot Disease onYa Pear.[D] Zheng Zhou, Henan agricultural university, 2008.

14. Xiting Bai, Xuewen Zhu, Lei Luo, J. Scie. Techn. Food Ind., 28, 216, 2007. 